\title{
Fireweed (Heartleaf nettle) Control in Pastures ${ }^{1}$
}

J. A. Ferrell ${ }^{2}$

\section{Introduction}

Fireweed (Urtica chamaedryoides) (Figure 1) is native to Florida, but has only recently become problematic. This winter annual species is commonly observed in north and central Florida pastures, particularly in bareground areas (near feeding pens and under fences) as well as along tree lines where forage grasses are less dense.

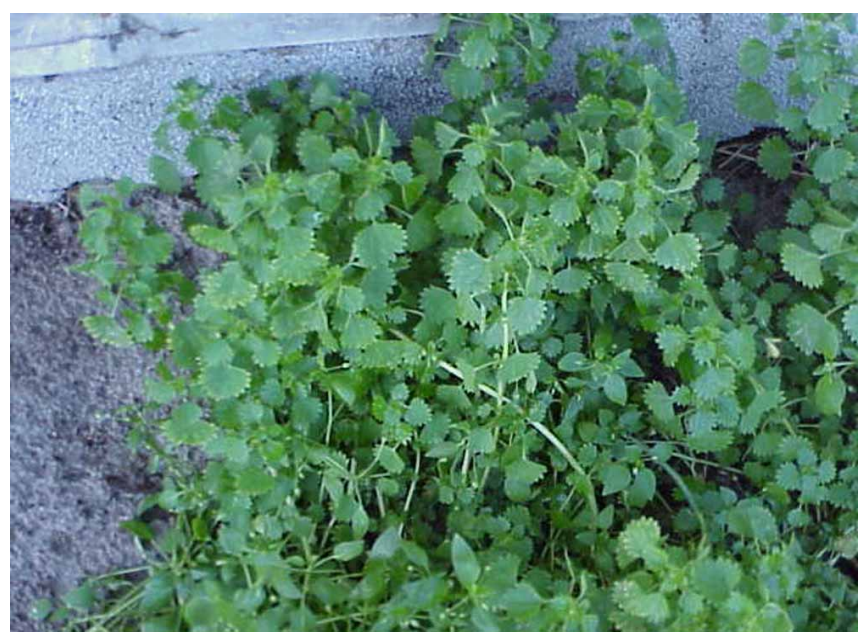
政 


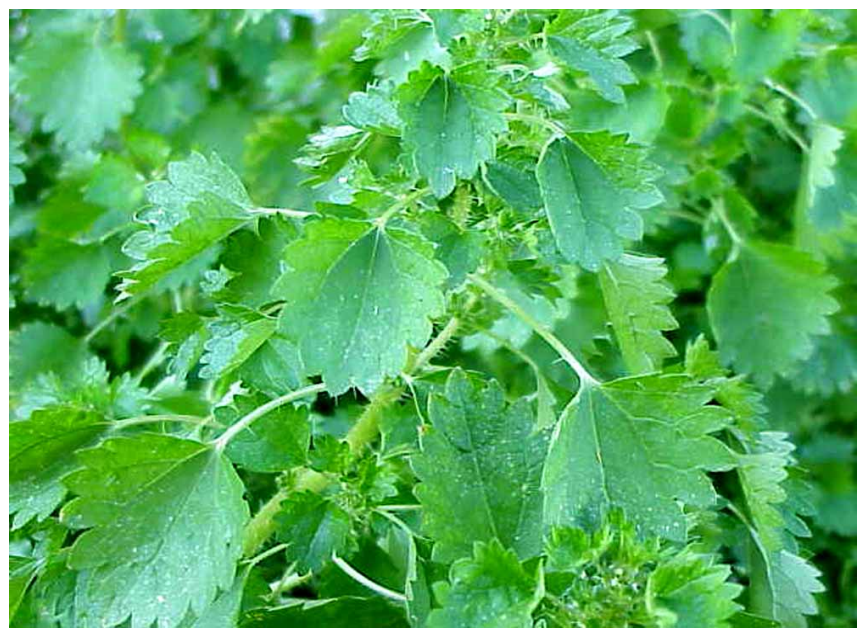

Figure 2. Fireweed leaves.

\section{Control}

Little work has been reported for control of this seasonal species. Therefore, experiments were conducted in March 2006 to determine which pasture herbicides are most effective on fireweed.

It was observed that 2,4-D and Telar were ineffective on fireweed (Table 1). Glyphosate, which can be applied when pasture grasses are dormant, provided as much as $80 \%$ control. However, in other experiments we have found glyphosate to be inconsistent on fireweed, sometimes providing as little as $30 \%$ control. Since glyphosate can severely injure pasture grasses that are not fully dormant, and because of its inconsistency on fireweed, we do not recommend the use of this product.

Weedmaster at $1.5 \mathrm{qt} / \mathrm{A}$ did not provide acceptable levels of control, but Milestone, Remedy, and Pasturegard were found to be highly effective. Within 2 weeks of application, over $90 \%$ of the fireweed plants were dead and the remaining individuals were yellow and dying. By 6 weeks after treatment, no fireweed could be found.

It is our recommendation that Milestone, Remedy, or Pasturegard herbicdies be used for effective control of fireweed. These herbicides can be applied any time of year to warm-season forage grasses. There are no grazing restrictions for beef cattle with these herbicides, but lactating dairy animals must be removed for 0 and 14 days with Milestone and Remedy, respectively, and one season for Pasturegard.
Mowing provides no benefit to control of this species. In fact, mowing has been found to result in smaller plants, but with many more stinging hairs. Additionally, the seed is surrounded by a sticky substance that can be transported by mower blades to areas not infested with this weed.

If not controlled, fireweed generally disappears in May with the onset of summer temperatures. 
Table 1. Control of fireweed with various herbicides.

\begin{tabular}{|c|c|c|c|c|}
\hline \multirow[t]{2}{*}{ Herbicide } & \multirow{2}{*}{$\begin{array}{c}\text { Rate } \\
\text { Product/A }\end{array}$} & \multirow{2}{*}{$\begin{array}{c}\text { Herbicide cost } \\
\$ \text { per acre }\end{array}$} & \multicolumn{2}{|c|}{$\%$ Control } \\
\hline & & & 2 wat $^{2}$ & 6 wat \\
\hline 2,4-D amine & $2 \mathrm{qt}$ & 6 & 10 & 0 \\
\hline Weedmaster & $1.5 \mathrm{qt}$ & 11 & 33 & 65 \\
\hline Remedy & $1 \mathrm{qt}$ & 25 & 93 & 100 \\
\hline Pasturegard & $1.5 \mathrm{qt}$ & 20 & 92 & 100 \\
\hline Milestone & $5 \mathrm{fl} . \mathrm{oz}$ & 14 & 95 & 100 \\
\hline Glyphosate & $1 \mathrm{qt}$ & 5 & 70 & 80 \\
\hline Telar & $0.5 \mathrm{oz}$ & 10 & 30 & 10 \\
\hline \multicolumn{5}{|c|}{$\begin{array}{l}\text { "These are approximate values taken from "Approximate herbicide pricing - 2006" (http://edis.ifas.ufl/WG056) } \\
\text { and do not include application costs. } \\
{ }^{2} \text { wat=weeks after treatment. }\end{array}$} \\
\hline
\end{tabular}

